\title{
The Composite Assessment of River Performance viewed from Function, Structure, Public Participation and Government Regulation
}

\author{
Putri Pamudya Wardhani ${ }^{1 *}$, Sobriyah ${ }^{2}$, Cahyono Ikhsan ${ }^{2}$ \\ ${ }^{I}$ A Student of Civil Engineering Master Program, Engineering Faculty, Surakarta Sebelas Maret University \\ ${ }^{2}$ Lecturers of Civil Engineering Master Program, Engineering Faculty, Surakarta Sebelas Maret University \\ *Corresponding author: putrilOpramudyawardhani@gmail.com
}

\begin{abstract}
River performance is a quantitative representation showing fairly good, requiring maintenance- or damaged conditions. The assessment is conducted to implement the maintenance with appropriate management. It is the manifestation of government, stakeholders, and community's anticipation to conduct repairing and maintenance before the damage occurring. The criterion of assessment is expressed in percentage. The case study in Pepe Baru River of Surakarta was conducted by designing the assessment of condition viewed from function, structure, public participation, and government regulation aspects. Indicator weighing was conducted using ANP (Analytic Network Process) method with Super Decision Beta software. The assessment of these components resulted in field weight. The assessment of function using Hec-Ras software, Structure aspect with visual observation, Public participation level was conducted using questionnaire distributed to the society with Guttman, Linkert scale method, and assessment according to government regulation. From the result of analysis, it could be found the indicator weight and field weight, so that the assessment of river performance was obtained. The result of performance assessment with $80 \%-100 \%$ score was categorized into good, $50 \%-79 \%$ into fair, and $0 \%-45 \%$ into poor. Considering the result of analysis on the performance analysis, it could be found the score of $74 \%$ indicating fair condition and the maintenance was required to improve the performance.
\end{abstract}

Keywords - river performance, assessment criteria, analytic network process.

\section{INTRODUCTION}

$\mathrm{R}$ iver performance is a quantitative representation showing poor, requiring maintenance or damaged condition. An assessment is made to conduct maintenance and management appropriately. It is the manifestation of anticipation made by government, those related, and community to repair and to maintain before the damage occurs. The assessment criteria is expressed in percentage. River maintenance is an activity needing many parties' attention absolutely. The intended river maintenance is any attempt aiming to preserve the function of river. The criteria of river assessment is the list of river components and its condition organized to determine the severity level of river [1]. Using criteria of river assessment, a quantitative description of river condition can be obtained, indicating whether the river is still in good condition, needs maintenance or has been damaged.

\section{METHOD}

In this research, data analysis starts with designing river condition assessment criteria by combining function, structure, public participation, and government regulation aspects using the existing literature. Then, from the result of condition assessment design, analysis on indicator weighing is conducted with SuperDecision Beta software help. This software is ANP (Analytic
Network Process) method aid in which the pairwisecomparison assessment (weighing) is obtained from the first questionnaire distributed to expert. The designated respondents in river maintenance area includes civil engineering lecturer of water field, consultant of water field, workers in water field and other respondents competent in river maintenance. Therefore, the output of weighing is the weight of component and subcomponent indicators. Then, the component assessment analysis is conducted based on function, structure, public participation, and government regulation aspects. When the function assessment is conducted in the field, data of rain (secondary data) is needed to obtain annual flow rate using nakayasu to be included into Hec-Ras, so that the extent to which the building in the river functions will be found out referring to the table of river assessment criteria mentioned in chapter 2 . Thus, the percentage of river function in the field is obtained. Next, the river assessment on structure aspect in the field has been studied by Bagas (2015), so that the percentage of structure aspect assessment has been obtained. In addition, data analysis can also be done to assess the public participation, using the second questionnaire so that it can be found how active the citizens are in public participation using Guttman and Likert scale and finally the percentage of government regulation is assessed based on the Directorate General of Natural Resource's Circulars. When all data have been processed, the percentage of river condition can be obtained from the combination of the four aspects by multiplying the 
indicator weight by percentage assessment in the field. The expected output is actual percentage river performance assessment. From this result, the components needing attention in river maintenance can be found.

\section{A. River Assessment Design}

A.1. Criteria Determination

The determination of river assessment criteria is made for each component of river is viewed from the combination of function, structure, public participation, and government regulation assessments.

\section{A.2. Weighing}

The weight of each river component is the combination of components comprising it and weight distribution for both supporting and composing component. The distribution of river component assessment is adjusted with sub component of building existing in the river. From the subcomponents of building existing, each of weights is found using ANP method estimation. The weight of each component is organized based on the questionnaire distributed to the expert or stakeholders to get more accurate output.

\section{A.3. Analytic Network Process (ANP)}

\section{A.3.1. ANP Software}

Data processing is carried out using ANP method with software SuperDecision Beta help and direct priorities data input method.

A.3.2. ANP implementation Stage

Priority decision making with ANP method has some stages. Those stages are explained by Yuksel, I \& Dagdeviren, M. (2007) as follows:

a. Organizing the problem model structure

The objective of model developed is determined by defining the influential element and criteria. Element, cluster, alternative and relationship occurring between elements are determined in this stage.

b. Developing pairwise-comparison matrix

In ANP method, decision making is assumed to make comparison of element importance for each level in pair. The pairwise comparison is carried out using ANP-19 scale, just like what is mentioned earlier. Mega (2013) explains that the comparison of importance organized is then transformed into matrix A. Aij value represents the relative importance value of each element on $i$-th row to the element of $j$-th column, for example aij $=\frac{w i}{w j}$. If there are n-elements to be compared, the comparison matrix A is defined as follow:

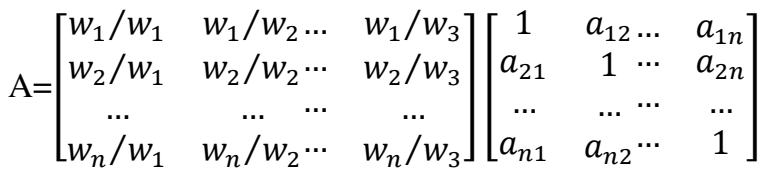

If pairwise comparison has been made completely, the priority vector w (called Eigen factor) is estimated using equation 2.2

A. $=\lambda \max . \mathrm{w}$

where:

$\mathrm{A}=$ pairwise comparison matrix
$\lambda \max =$ Largest Eigenvalue of $\mathrm{A}$

$\mathrm{W}=$ eigen factor

\section{d. Estimating Consistency Ratio}

Consistency ratio is the one representing whether or not the assessment given by experts is consistent. Consistent Index (CI) of a comparison matrix is estimated using equation 2.3 .

$C R=\frac{\lambda \max -n}{n-1}$

where:

$\lambda \max =$ largest eigenvalue of pairwise comparison matrix $\mathrm{n} \times \mathrm{n}$

$\begin{array}{ll}\mathrm{n} & =\text { number of items compared } \\ \mathrm{CI} & =\text { Consistency Index }\end{array}$

The consistency ratio is obtained by comparing consistency index (CI) and random consistency index (RI) as expressed in equation 2.4.

$C R=\frac{C I}{R I}$

where:

$\mathrm{CR}=$ Consistency Ratio

$\mathrm{CI}=$ Consistency Index

$\mathrm{RI}=$ Random Consistency Index

RI value is dependent on the number of elements compared (n). RI value to $\mathrm{n}$ is shown in Table 1 .

\section{e. Developing Supermatrix}

Supermatrix is the matrix consisting of submatrices organized in a set of relationship between two levels existing in the mode. Saaty (2006) explained that when a model has $n$ cluster, the elements of each cluster will interact each other. When the cluster is assumed to be $\mathrm{Ch}$ where $\mathrm{h}=1,2, \ldots, \mathrm{n}, n h$ elements are assumed to be eh1, eh2, ..., ehnh. The effect of an element on another in a model can be seen below:

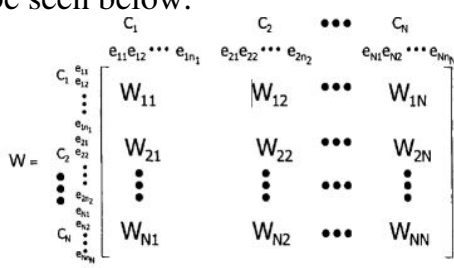

With block i, j of this matrix:

$$
\mathrm{W}_{\mathrm{ij}}=\left[\begin{array}{cccc}
w_{i 1} & w_{i 1} & \cdots & w_{i 1} \\
w_{i 2} & w_{i 2}^{(j 2)} & \cdots & w_{i 2}^{(j n j)} \\
& & \cdots & \cdots \\
w_{i n i}(j i) & w_{i n i}(j 2) & \cdots & w_{i n i}(j n j)
\end{array}\right]
$$

f. Selecting the best alternative 


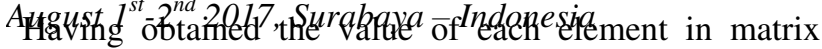
limit, the next step is to estimate the value of elements corresponding to ANP model developed. The result with highest priority scale is the best alternative.

\section{g. Weight Indicator}

The indicator weight is determined by doing the kuisiner with the respondents of experts in the field of river maintenance in between. Water construction consultant, lecturer. And the competent party in the field of river maintenance

\section{A.4.River Condition Assessment}

The value of river condition is determined by summing the weights of river condition, structure and public participation.

$$
\text { River condition }=\mathrm{BF}+\mathrm{BS}+\mathrm{BP}+\mathrm{BPP}
$$

$$
\begin{array}{ll}
\mathrm{BF} & =\text { Function Condition Weight }(\%) \\
\mathrm{BS} & =\text { Structure Condition Weight }(\%) \\
\mathrm{BP} & =\text { Public Participation Weight }(\%) \\
\mathrm{BPP} & =\text { Government Regulation Weight }(\%)
\end{array}
$$

Assessment of River Performance on the Field Based on Functional Aspects

\section{A.5. Nakayasu Synthetic Unit Hydrograph}

The hydrograph used in this study used the Nakayasu hydrograph. Nakayasu synthetic unit syntheses developed in Japan are also widely applied in Indonesia. This HSS generally gives relatively careful results. This HSS is also estimated based on basin characteristics with some empirical formulas, below.

$$
\begin{array}{ll}
Q_{\text {max. }}=\frac{1}{3.6} A R_{0} /\left(0.3 T_{p}+T_{0.3}\right) . \\
T_{p}=T_{g}+0.8 t_{r} & \\
T_{0.3}=\alpha T_{g} & \\
T_{g}=0.4+0.058 L & \text { For } \mathrm{L}>15 \mathrm{~km} \\
T_{g}=0.21 L^{0.7} & \text { for } \mathrm{L}<15 \mathrm{~km}
\end{array}
$$

The Nakayasu unit hydrograph equation is as follows:

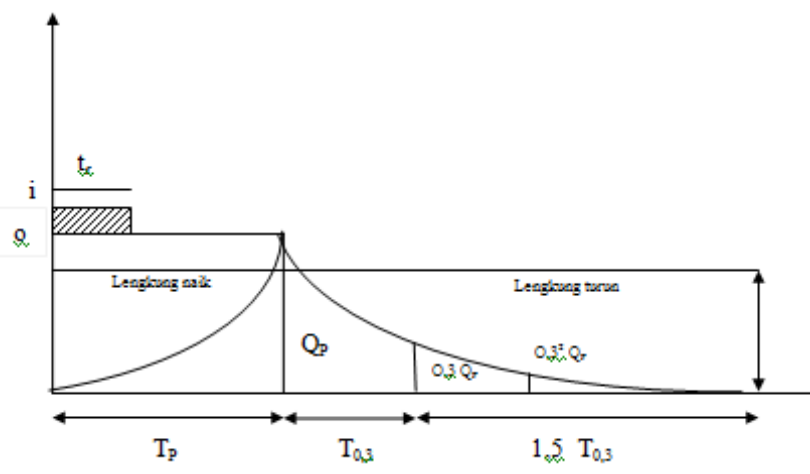

Figure 1. Nakayasu Synthetic Unit Hydrograph

$$
Q t=\left(\frac{t}{T_{p}}\right)^{2.4} Q p
$$

On the down / recession curve $\left(\mathrm{t}>\mathrm{T}_{\mathrm{p}}\right)$

1. Value interval: $0 \leq \mathrm{t} \leq\left(\mathrm{T}_{\mathrm{P}}+\mathrm{T}_{0,3}\right)$

$$
Q_{(t)}=0.3^{\left(\frac{t-T_{p}}{T_{0.3}}\right)} Q p
$$

Value interval: $\left(\mathrm{T}_{\mathrm{P}}+\mathrm{T}_{0,3}\right) \leq \mathrm{t} \leq\left(\mathrm{T}_{\mathrm{P}}+\mathrm{T}_{0,3}+1,5 \mathrm{~T}_{0,3}\right)$

$$
Q_{(t)}=0.3^{\left(\frac{t-T_{p}+0.5 T_{0.3}}{1.5 T_{0.3}}\right)} Q p
$$

Value interval: $\mathrm{t}>\left(\mathrm{T}_{\mathrm{P}}+\mathrm{T}_{0,3}+1,5 \mathrm{~T}_{0,3}\right)$

$$
Q_{(t)}=0.3^{\left(\frac{t-T_{p}+1.5 T_{0.3}}{2 T_{0.3}}\right)} Q p
$$

with:

$$
\begin{array}{ll}
\mathrm{A} & \text { : Large basin }\left(\mathrm{km}^{2}\right), \\
\mathrm{R}_{0} & \text { : specific rainfall }(=1 \mathrm{~mm}), \\
\mathrm{T}_{\mathrm{p}} & \text { : peak time (hours), } \\
\mathrm{T}_{0.3} & \text { : time form peak flood to } 0.3 \mathrm{Q}_{\max } . \\
& \text { (hours), } \\
\mathrm{T}_{\mathrm{g}} & \text { : time lag } \mathrm{Q}_{\max } \text { (hours), } \\
\mathrm{t}_{\mathrm{r}} & \text { : unit time }(=1 \text { hour }), \\
\alpha & \text { : coefisien }(1.5-3.5), \\
\mathrm{L} & \text { : long river main }(\mathrm{km}) .
\end{array}
$$

\section{Water Forum Profile}

The flow depth along the channel can be calculated by finishing Differential equations for flow are changed irregularly. Counts usually beginFrom a look where the relationship between the water level (depth) and the discharge is known. The appearance is known as the control point. The water profile profile count is usually done gradually from a look to the next look which is quite small so that the water level between the two looks can be approached with a straight line. If the flow is subcritical the count starts from the most downstream

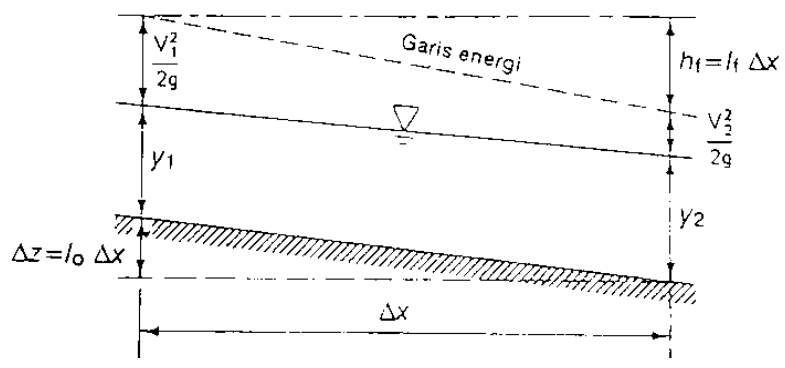

Figure 2. Direct step method

point and advances upstream, while if the flow is supercritical the count is done from upstream to

1. On the rising $\operatorname{arch}\left(0<\mathrm{t}<\mathrm{T}_{\mathrm{p}}\right)$ 
downstream [2]. The step-by-step method is done by dividing the channel into a number of pounds with length $\Delta \mathrm{x}$. Starting from the downstream border where the hydraulic characteristic on the face is known, the water depth is calculated at the upstream view. The calculation procedure is continued to look at the next upstream, until water depth is obtained along the channel. The accuracy of the count depends on the length of the pias, the smaller $\Delta \mathrm{x}$ the more thorough the results obtained (Bambang Triatmodjo).

Figure 2.shows the channel line between the 1 and 2 faces that are $\Delta \mathrm{x}$ apart. Assuming that the speed distribution is uniform at the cross-sectional and Coriolis coefficients one, then:

By knowing the flow characteristics and the roughness of one look, the velocity and depth of flow in the other can be calculated using the above equation. The slope of the If energy line is the average value in terms of 1 and 2, which can be based on the Manning or Chezy equation. If the flow characteristics in both faces are known, the distance between the faces can be calculated by the above equation (Bambang Triatmodjo, 2003).

2.7. Community Participation in River Management (Muttaqien 2006 in Apriliana 2015) Within the framework of regional autonomy, the central government has given local people the opportunity and freedom to organize and manage the interests of local communities according to their own initiatives based on the aspirations of the people [3]. Article 10 paragraph 1 of Law No.32 / 2004 on Regional Autonomy, stipulates that the regions have authority to manage natural resources available in their area and are responsible for maintaining environmental sustainability in accordance with the laws and regulations. Conceptually, regional policy changes are mainly directed to:

1. Enhance management democracy

2. Increasing community participation in regional development management.

3. Improving regional development equity and justice

4. Taking into account the diversity of regions in regional development

5. Taking into account the potential of the region in the process of managing regional development.

Community participation in every stage of development (drainage network system) according to Pranoto SA, in Muttaqien 2006. Can be described as follows:

1. Survey and Investigation: provide local location and condition information.

2. Planning: Approval, agreement and use

3. Land acquisition: Giving convenience, facilitating the process

4. Development: Assist supervision and engage in implementation

5. Operation and maintenance: engage in the implementation, participate maintain, report if there is damage.
6. Monitoring and evaluation: Providing real data in the field about impacts that occur postdevelopment.

From the understanding and criteria on community participation above, in this thesis will be analyzed the level of community participation in the study location according to the views of the community and this is shown in: percentage of the level of community participation

The above participation parameters will be obtained from interviews with RT / RW Management in the study location and then followed by the delivery of questionnaires to the community as respondents.

\subsubsection{Population and Sample}

Population is the whole subject of research. If one wishes to examine all the elements present in the study area, the research is a population study or population study (census, 2007).

$$
N=\frac{N}{N \cdot d^{2}+1}
$$

Where:

$\mathrm{n}=$ Number of Sample,

$\mathrm{N}=$ Total Population,

$\mathrm{d}=$ Standard error / error rate.

To test the validity of the instrument, searched by correlating each item of the measuring instrument with the total score. For items of questions that have a value rhitunglebih rtabeldecause it is a valid questionnaire item. For the value of rhitunglebih rtabeld value can be said that the question item is not alid so it must be repaired or issued [4].

Rebiebilitas test is used to know the consistency of the instrument / questionnaire used as a measuring instrument. Whether the measuring instrument is used is reliable and remains consistent or has good stability and still shows a fixed result when the test is repeated. The reliability test used in the research is by Alpha Cronbach's method with the following 2.42 equation (Dwi Priyanto, 2008)

Assessment on each answer of the questionnaire question items in the study can be calculated using 4 scales (Sugiyono, 2008) namely [5]:

\section{A. Linkert Scale}

The linkert scale is often used to express the attitude, opinion and perception of a person or group of people about social events or phenomena. The answer of each instrument item using the Linkert Scale is madunai gradation and very positive until very negative and vice versa. Research instruments using Linkert scale can be created in the form of checklist or multiple choice. Linkert scale calculations can be done manually or using the application SPSS AND LISREL The Linkert scale is by multiplying the number of respondents with each item 
The Third International Conference on Civil Engineering Research (ICCER)

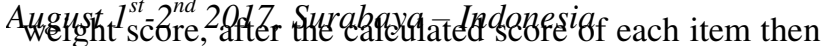
summed. To mmminterpretasikan total score of observations that is by dividing the score of the results of the calculation of the questionnairewith the highest total score

\section{B. Guttman Scale}

The Guttman scale is used to measure the instrument with a firm answer item that is "yes-no", "right-wrong" and others. Research instruments using Guttman scale can be made in the form of checklist or multiple choice. Calculations using Guttmen scale on Linkert scale.

\section{Semantic Differential}

The scale of semantic differential measurement was developed by Osgood. This scale is used to measure attitudes, only the form is not double choice or checklist but arranged in continuum line.

\section{Rating Scale}

Rating Scale is a scale used to calculate the item questionnaire scores with raw data obtained in numerical form then interpreted in a qualitative sense.

\section{RESULT AND DISCUSSION}

Analisis and Discussion

1. Design criteria for merging

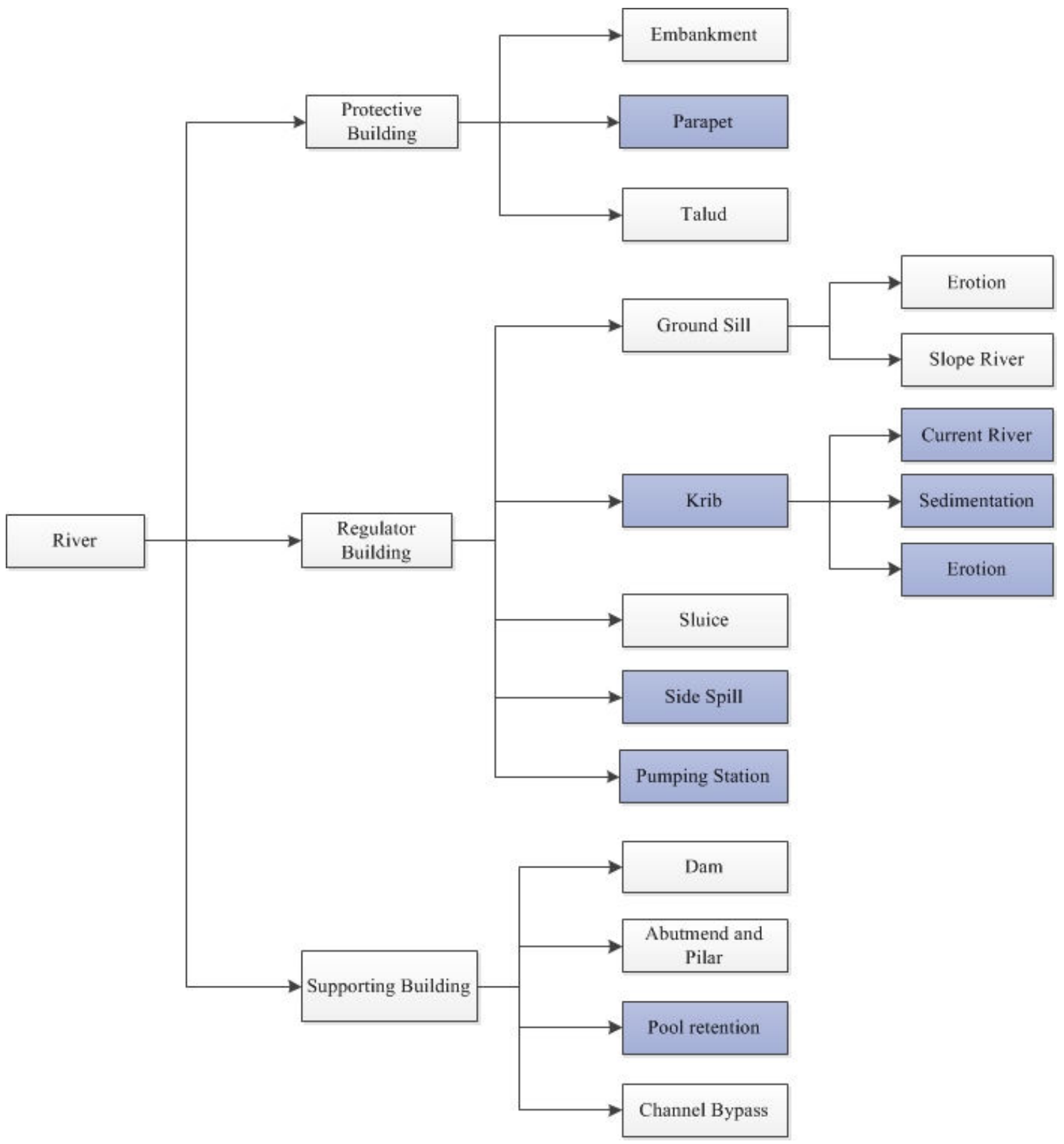

Figure 3. Design criteria for merging 


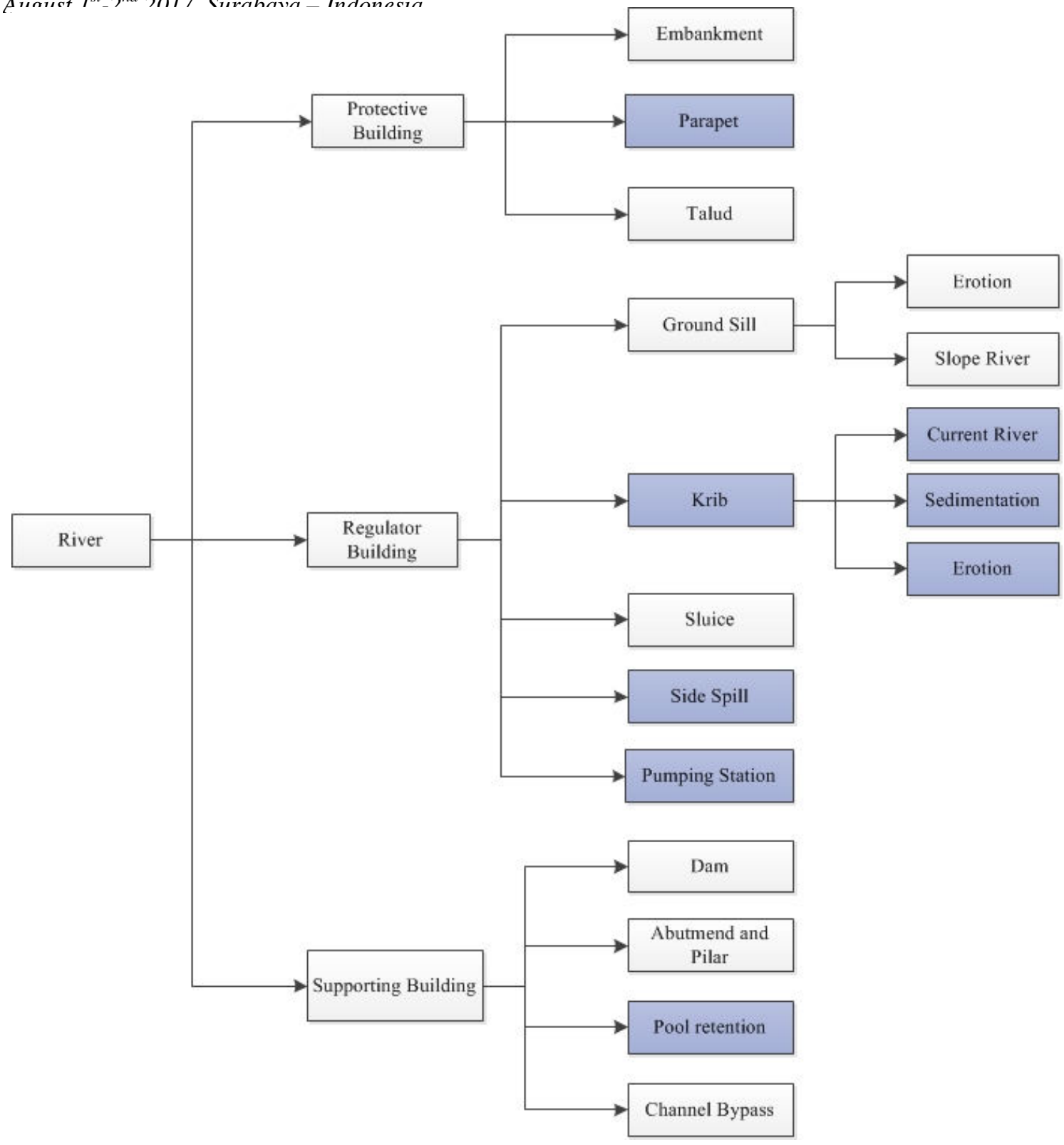

Figure 4. Results Weighted indicator using Software SuperDeasicion Beta

Table 2. Times flood debit when re-done

\begin{tabular}{cc} 
Table 2. Times flood debit when re-done \\
\hline Reissue & Flood debit \\
2 Years & $225,2724 \mathrm{~m}^{2} / \mathrm{s}$ \\
5 Years & $307,4975 \mathrm{~m}^{2} / \mathrm{s}$ \\
10 Years & $363,1464 \mathrm{~m}^{2} / \mathrm{s}$ \\
25 Years & $434,6939 \mathrm{~m}^{2} / \mathrm{s}$ \\
50 Years & $488,8722 \mathrm{~m}^{2} / \mathrm{s}$ \\
100 Years & $544,0174 \mathrm{~m}^{2} / \mathrm{s}$ \\
\hline
\end{tabular}

The results obtained from flood debit calculations for some reworking for Then used as one of the input data of HEC-RAS program Aims to find out the profile of flood water in the Pepe Baru River as it happens flood. River hydraulic analysis is used to determine the profile of river water level on Research sites on the Pepe Baru River. River hydration is calculated by Using the help of HEC-RAS software version 4.1. As for the calculations Carried out using cross section of the river at a certain distance Which is divided starting from peg 0 +000 to peg $10+345$ according to the data which are owned 
Regional Conference in Civil Engineering (RCCE)

The Third International Conference on Civil Engineering Research (ICCER)

August $1^{\text {st }}-2^{\text {nd }}$ 2017, Surabaya - Indonesia

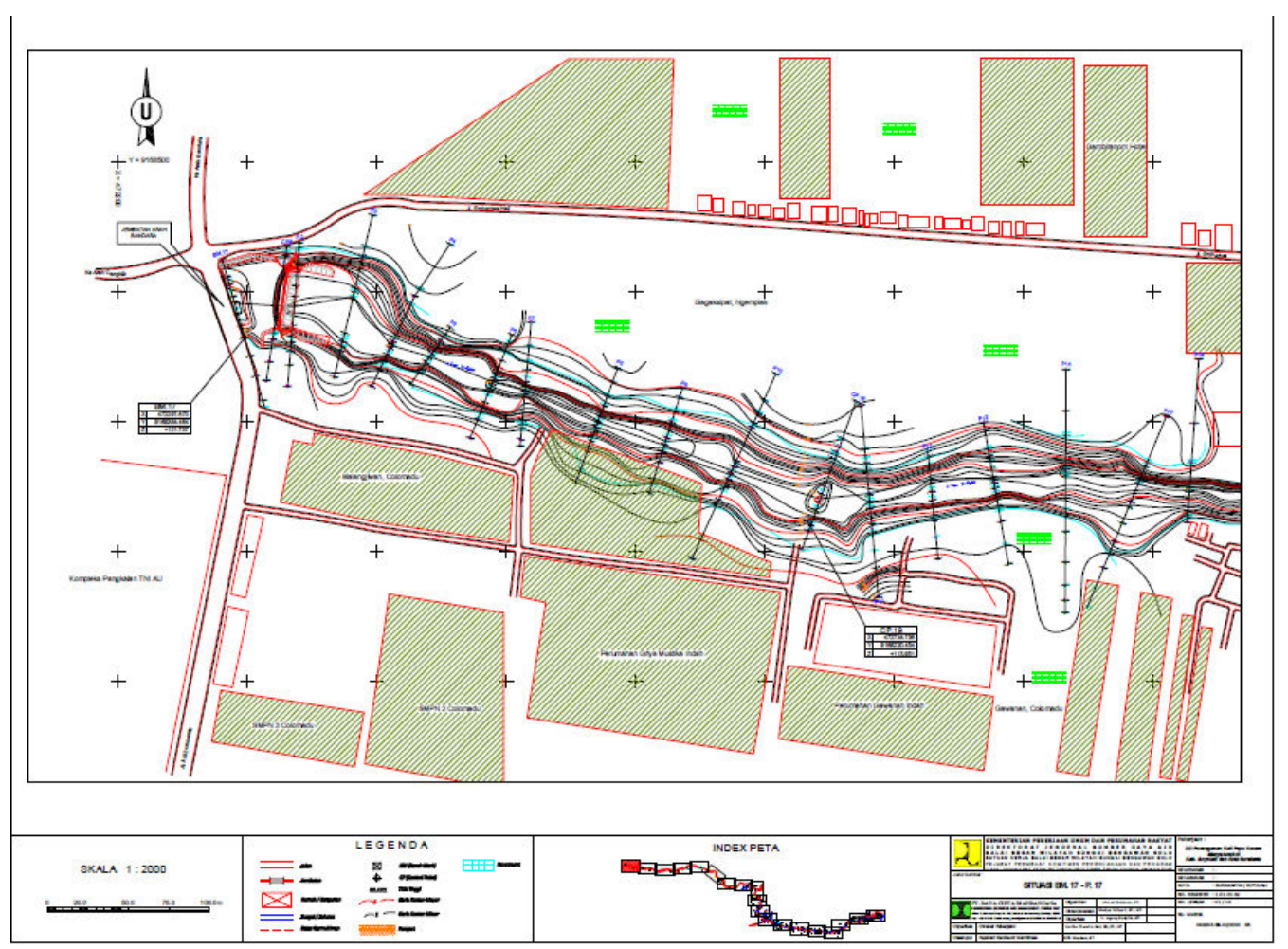

Figure 5. Cross section

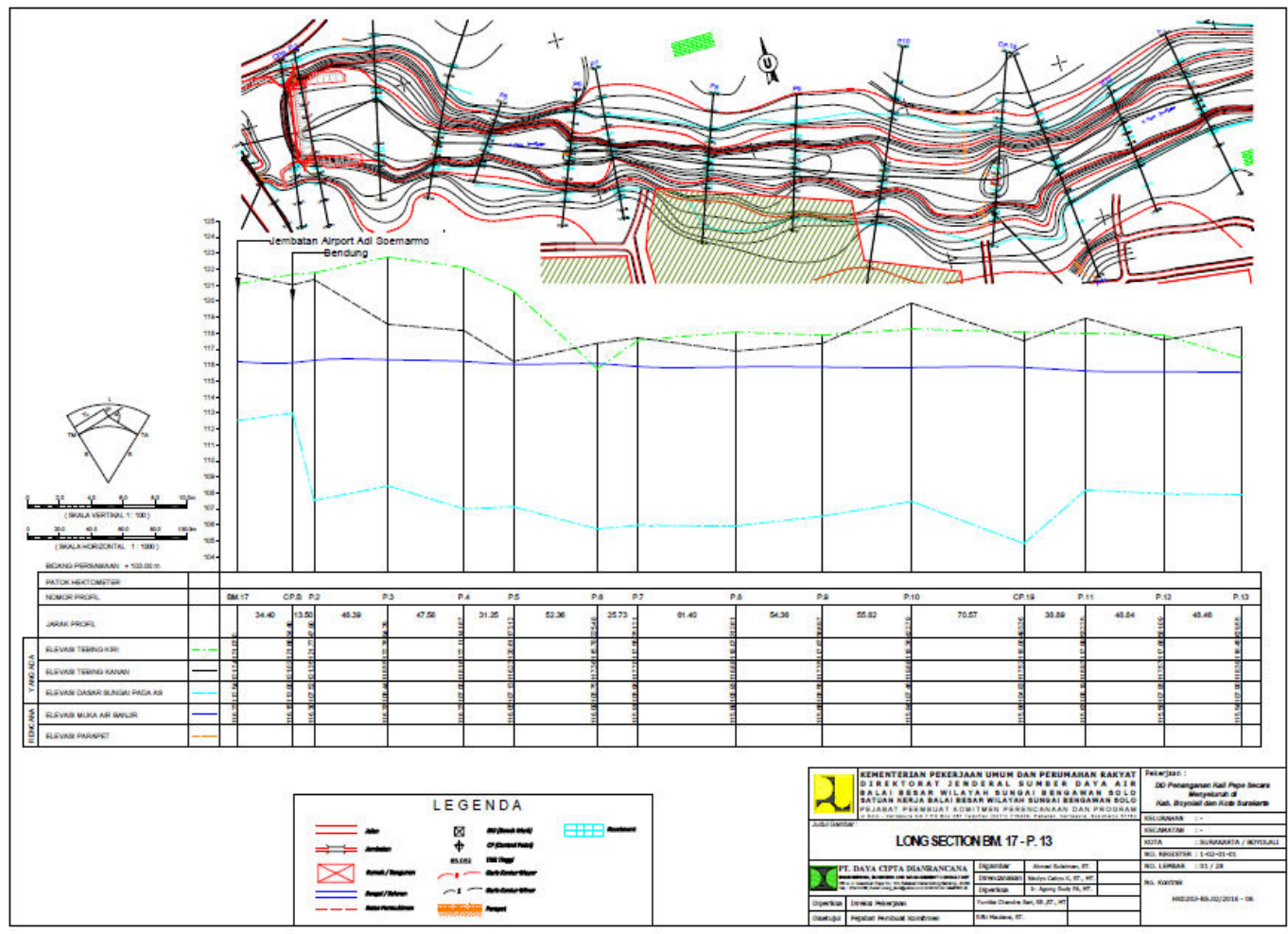

Figure 5. Long profile 
The Third International Conference on Civil Engineering Research (ICCER)

August $1^{\text {st }}-2^{\text {nd }}$ 2017, Surabaya - Indonesia

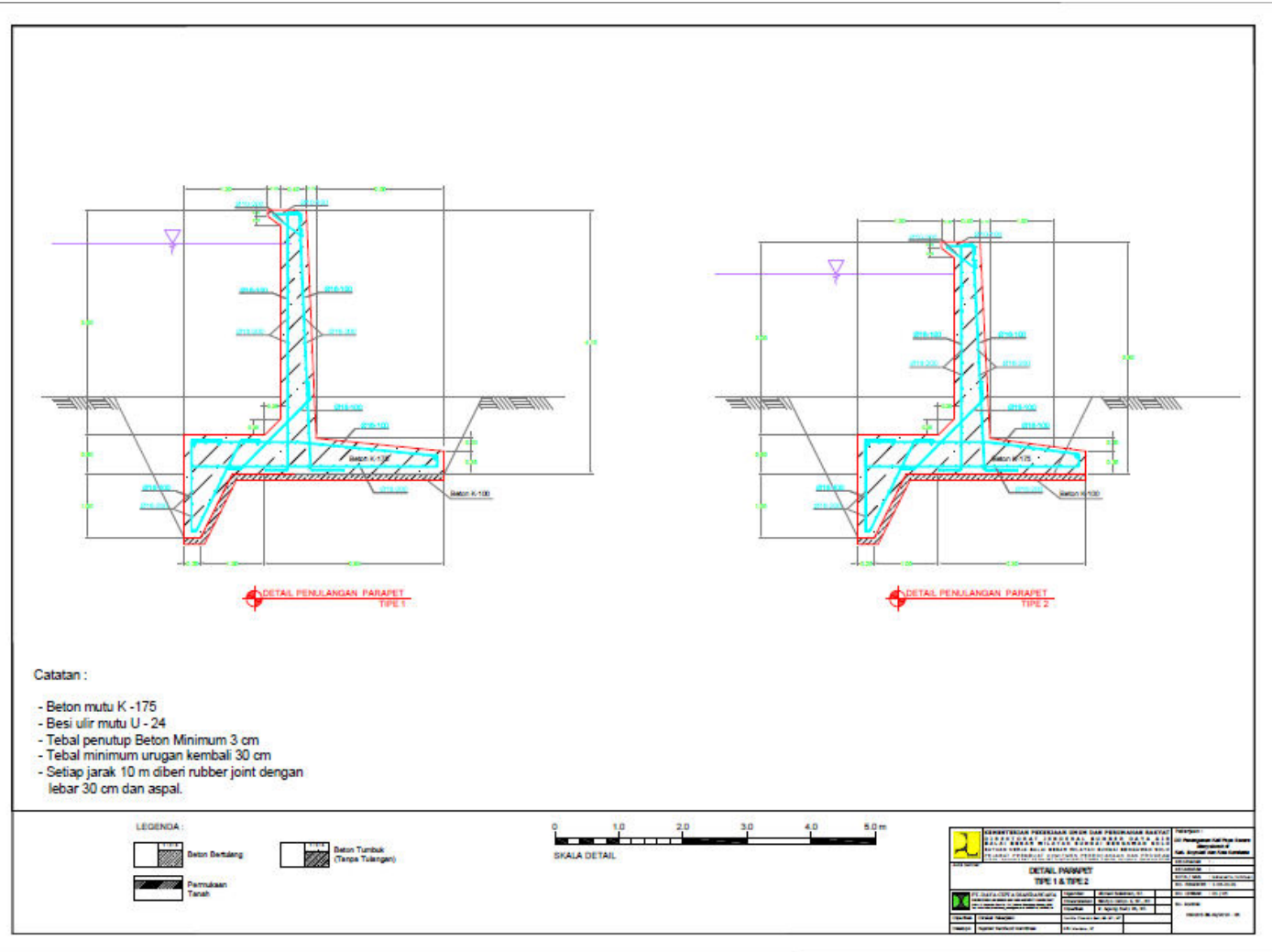

Figure 7. Parapet Repeating Details

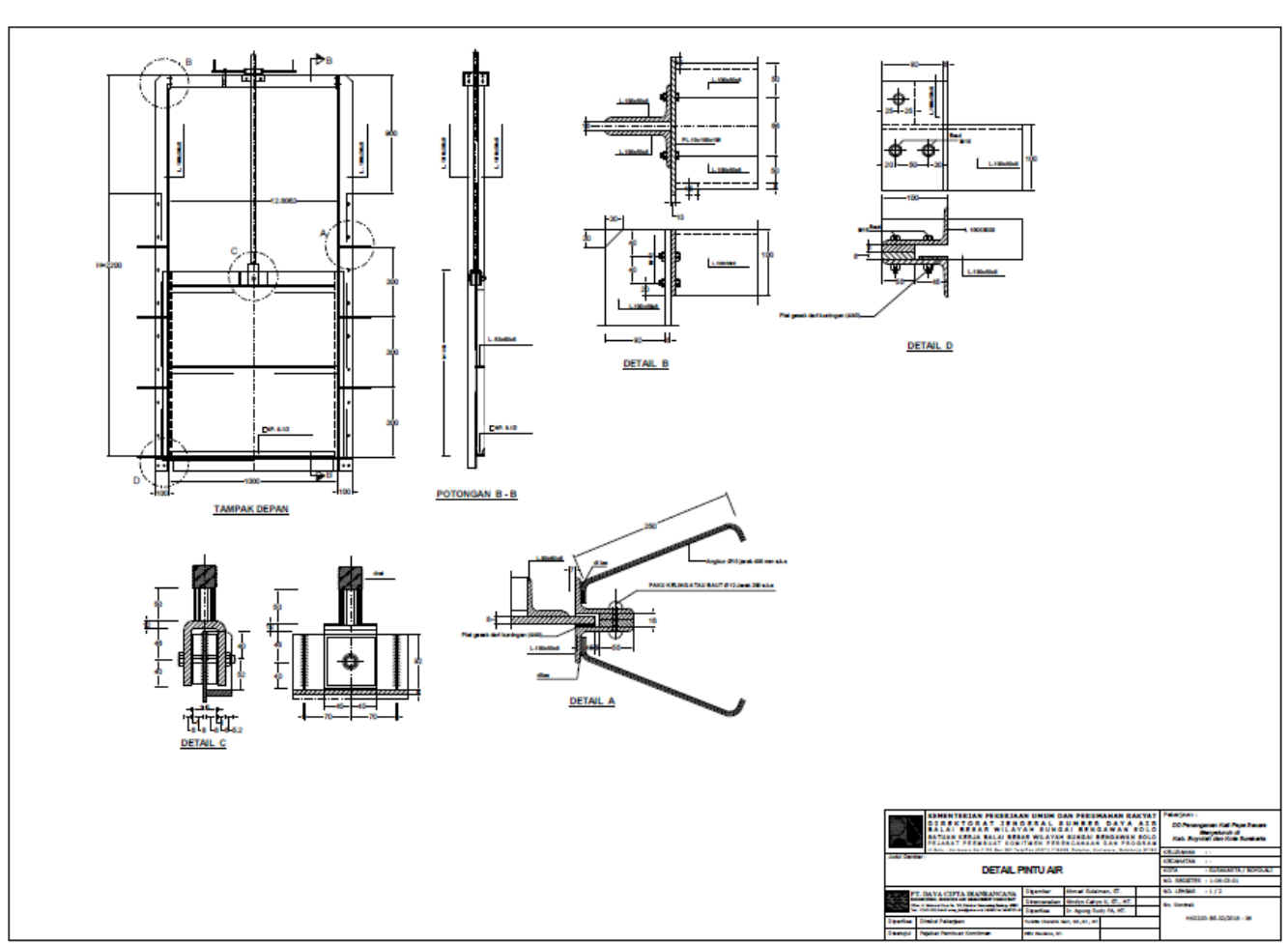

Figure 8. A typical water gate 


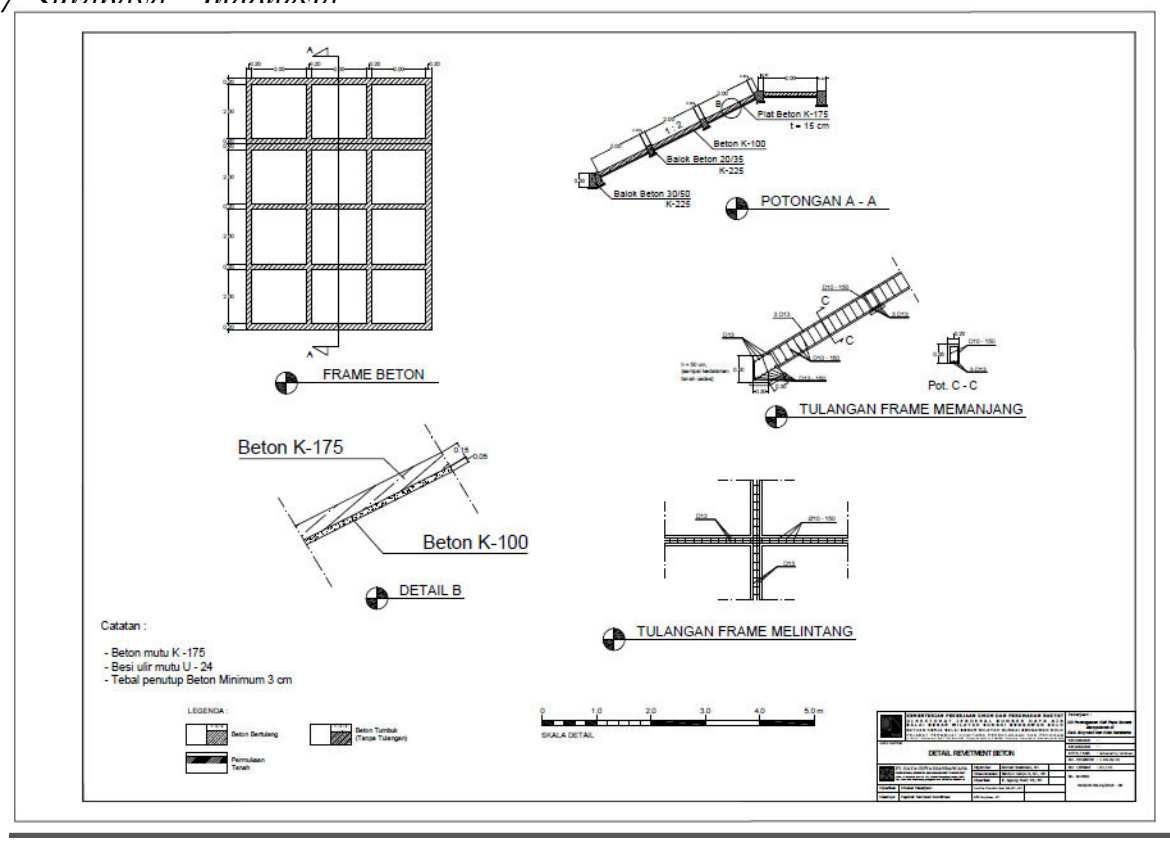

Figure 9.Typical Revetment of Pepe

Table 3 Example of Calculation Result

\begin{tabular}{llllll}
\hline No. & Building Section Observed & Location & Water velocity & Value & Category \\
\hline 1 & Protector of Talud against & coordinat & 2,893 & 57 & Quite fungtional \\
& Coordinate Water punch & X 110'50',22,53', BT & & & \\
& & Y 7'33''14,12',LS & & & \\
\hline
\end{tabular}

Table 4. Assessment of structural aspects

\begin{tabular}{|c|c|c|c|c|c|}
\hline No. & Building Section Observed & Location & $\begin{array}{l}\text { Result } \\
\text { Analysis }\end{array}$ & Value & Photo \\
\hline 1 & Embankment & $\begin{array}{l}\text { coordinat } \\
\text { X 110'49',1', BT } \\
\text { Y 7'32',60',LS }\end{array}$ & $\begin{array}{l}\text { High Cycle } \\
\text { safe enough to } \\
\text { prevent runoff }\end{array}$ & 85 & \\
\hline
\end{tabular}

Table 5. Society participation

\begin{tabular}{|c|c|c|c|c|c|}
\hline No. & Building Section Observed & Location & $\begin{array}{l}\text { Result of } \\
\text { public opinion }\end{array}$ & Value & Photo \\
\hline 1 & Embankment & $\begin{array}{l}\text { Koordinat } \\
\text { X 110'49,'1,' BT } \\
\text { Y 7’32',60"'LS }\end{array}$ & $\begin{array}{l}\text { High Could } \\
\text { hold flood }\end{array}$ & 85 & \\
\hline
\end{tabular}

River Condition $=\mathrm{BF}+\mathrm{BS}+\mathrm{BP}+\mathrm{BPP}$

$\mathrm{BF}=$ Weight Condition Function $(\%)$

$\mathrm{BS}=$ Structure Condition Weight $(\%)$

$\mathrm{BP}=$ Weight of Community Participation $(\%)$

$\mathrm{BPP}=$ Weight Government regulations $(\%)$

River Condition $=76 \%+72 \%+73 \%+74 \%$

$=73.74 \%$

mentor who show me by they example what a good scientist should be.

\section{IV.CONCLUSION}

Percentage river performance in this research is $74 \%$

\section{ACKNOWLEDGEMENTS}

I would especially like to thank Prof.Dr.Ir.Sobriyah.,MS and Dr.Cahyono Ikhsan S.T.,M.T. as my teacher and

I would like to thank my parents whose love me in whatever i pursue. They are the ultimate role models. 


\section{REFERENCE}

[1] Bagas, "Desain kriteria penilaian kondisi sungai berdasarkan aspek struktur bangunan (studi kasus sungai Pepe baru Surakarta)," 2015.

[2] B. Trihatmojo, Hidraulika II. Yogyakarta: Publisher Beta Offset, 2003.

[3] Apriliana, "Evaluasi kinerja jaringan drainase kelurahan gandekan, kecamatan jebres, kota surakarta (sub sistem das kali Pepe hilir)," 2015.

[4] D. Prayitno, Mandiri Belajar SPSS. Yogyakarta: Mediakkom, 2008.

[5] Sugiyono, Metode Penelitian Pendekatan Kuantitatif, Kualitatif dan $R 7 n$ D. Bandung: Penerbit Alfabeta, 2013. 